\title{
EDUKASI BAGI CALON PENGANTIN TENTANG ANEMIA GIZI DAN KURANG ENERGI KRONIK DI KOTA PAREPARE
}

\section{EDUCATION FOR PROSPECTIVE BRIDES ON NUTRITIONAL ANEMIA AND CHRON- IC ENERGY IN PAREPARE CITY}

\author{
Suriah $^{1}$, Citrakesumasari ${ }^{2}$, Awaluddin ${ }^{3,}$ Ahmad Yani ${ }^{4}$ \\ ${ }^{1}$ Departemen Promosi Kesehatan dan Ilmu Perilaku, Fakultas Kesehatan Masyarakat Universitas Hasanuddin \\ ${ }^{2}$ Departemen Gizi, Fakultas Kesehatan Masyarakat Universitas Hasanuddin \\ ${ }^{3}$ Departemen Kesehatan dan Keselamatan Kerja, Fakultas Kesehatan Masyarakat \\ ${ }^{4}$ Departemen Promosi Kesehatan dan Ilmu Perilaku, Fakultas Kesehatan Masyarakat Universitas Muhammadiyah Palu \\ Email Korespondensi : suriah_74@yahoo.com
}

\begin{abstract}
Abstrak
Kegiatan ini bertujuan memberikan edukasi tentang pencegahan anemia gizi dan KEK pada ibu hamil di kota Parepare. Proses kegiatan ini meliputi; 1). Sosialisasi dan bina suasana, 2). Pelatihan komunikator lokal, dan 3). Edukasi tentang pencegahan anemia gizi dan KEK pada ibu hamil yang dilakukan oleh kader posyandu dan atau tokoh masyarakat kepada calon pengantin dalam acara Mappacci. Kegiatan ini menghasilkan; 1). Komitmen dari kepala KUA dari 4 kecamatan, kader posyandu, bidang gizi dan promosi kesehatan dinkes kota Parepare untuk mendukung pelaksanaan kegiatan, 2). Terlatihnya 10 orang komunikator lokal yang terdiri dari unsur kader posyandu dan tokoh masyarakat di kecamatan Bacukiki Barat, dan 3). Proses edukasi oleh komunikator lokal kepada calon pengantin dalam acara Mappacci. Berdasarkan hasil kegiatan pengabdian ini, diharapkan komunikator lokal akan terus memberikan informasi yang berkelanjutan kepada calon pengantin pada acara Mappacci di kota Parepare yang dilengkapi dengan booklet saku edukasi. Pihak KUA dan Dinas Kesehatan kota Parepare agar dapat menyebarluaskan hasil kegiatan ini sehingga seluruh kecamatan yang ada di kota Parepare terpapar tentang pencegahan anemia gizi dan KEK pada ibu hamil yang telah dimulai di kecamatan Bacukiki Barat.
\end{abstract}

Kata Kunci : Edukasi, calon pengantin, komunikator lokal, anemia gizi dan KEK, Mappacci

\begin{abstract}
This activity aims to provide education about the prevention of nutritional anemia and chronic energy deficiency in pregnant women in the town of Parepare. The process of this activity includes; 1). Socialization and cultivation atmosphere, 2). Training of local communicators, and 3). Education on prevention of nutritional anemia and chronic energy deficiency in pregnant women conducted by posyandu cadres and / or community leaders to prospective brides in Mappacci event. This activity generates; 1). Commitment from KUA heads from 4 sub-districts, posyandu cadres, nutrition and health promotion of Parepare city health service to support the implementation of activities, 2). Trainings of 10 local communicators consisting of elements of Posyandu cadres and community leaders in the district of Bacukiki Barat, and 3). The process of education by local communicators to the prospective brides in Mappacci event. Based on the results of this devotional activity, local communicators are expected to continue to provide continuous information to the prospective brides at Mappacci event in Parepare city which is equipped with educational pocket booklets. Parties KUA and Parepare City Health Office in order to disseminate the results of this activity so that all districts in the city of Parepare exposed on prevention of nutritional anemia and chronic energy deficiency in pregnant women who have begun in the district of Bacukiki Barat
\end{abstract}

Keywords: Education, prospective brides, local communicators, nutritional anemia and chronic energy deficiency, mappacci 


\section{PENDAHULUAN}

Anemia merupakan keadaan rendahnya konsentrasi hemoglobin $(\mathrm{Hb})$ atau hematokrit berdasarkan nilai ambang batas (referensi) yang disebabkan oleh rendahnya produksi sel darah merah (eritrosit) dan $\mathrm{Hb}$, meningkatnya kerusakan eritrosit (hemalisis), atau kehilangan darah yang berlebihan (Citrakesumasari, 2012). Sedangkan Kekurangan Energi Kronik (KEK) adalah keadaan dimana wanita mengalami kekurangan gizi (kalori dan protein) yang berlangsung lama atau menahun. KEK ditandai dengan hasil pengukuran Lingkar Lengan Atas (LILA) kurang dari 23,5 cm. ${ }^{1}$

Hasil Riset Kesehatan Dasar (Riskesdas) tahun 2013 yang dilakukan pada 33 provinsi di Indonesia dan 497 kota atau kabupaten memperlihatkan presentase anemia pada ibu hamil yakni $37,1 \%$ (ibu hamil dengan kadar $\mathrm{Hb}$ kurang dari 11,0 g/dl), dengan proporsi yang hampir sama antara wilayah perkotaan $(36,4 \%)$ dan perdesaan (37,8\%).2 Beberapa hasil penelitian berikut menunjukkan ada keterkaitan antara kejadian KEK dan anemia pada ibu hamil. Hasil penelitian Rahmaniar (2013), menunjukkan bahwa ada hubungan yang bermakna antara risiko KEK dengan kejadian anemia pada ibu hamil. Ibu hamil yang berisiko KEK berpeluang menderita anemia 2,76 kali lebih besar dibandingkan dengan yang tidak berisiko.3 Demikian pula hasil penelitian dari Aminin, Wulandari dan Lestari (2014), menyimpulkan bahwa terdapat hubungan kekurangan energi kronis (KEK) dengan kejadian anemia pada ibu hamil. Dari 31 responden ibu hamil di Puskesmas Kota Tanjungpinang tahun 2014 pada kelompok KEK, kejadian anemia lebih besar $(88,9 \%)$ dibandingkan dengan yang tidak anemia $(11,1 \%)$, pada kelompok tidak KEK, kejadian anemia lebih kecil $(23,1 \%)$ dibandingkan ${ }_{4}$ dengan yang tidak anemia $(76,9 \%)$ pada nilai $\mathrm{p}=0,001 .^{2}$,

Data dari dinas kesehatan provinsi Sulawesi Selatan tahun 2011 memperlihatkan bahwa kabupaten/kota dengan angka prevalensi anemia gizi ibu hamil yang cukup tinggi antara lain; Kota Makassar sebanyak 388 ibu hamil, Kabupaten Barru sebanyak 135 ibu hamil, Kabupaten Sidrap sebanyak 126 ibu hamil, Kabupaten Bantaeng dengan $121 \mathrm{ibu}$ hamil dan Kabupaten Gowa sebanyak $120 \mathrm{ibu}$ hamil. Sedangkan data anemia gizi dan KEK pada ibu hamil tiga tahun terakhir dari salah satu kota di Sulawesi Selatan yakni kota Parepare tahun 2014 (695 anemia, $143 \mathrm{KEK}$ ), tahun 2015 (271 anemia, $130 \mathrm{KEK}$ ) dan tahun 2016 naik lagi 671 anemia dan 281 KEK. $^{5}$

Masalah anemia gizi dan KEK tidak terjadi dengan serta merta pada ibu hamil. Masalah ini bisa dihindari dengan memberikan informasi lebih awal kepada calon ibu dalam hal ini calon pengantin mengenai kedua masalah gizi tersebut (Citrakesumasari, Susilowati, Suriah dan Bohari, 2012). Selama ini pendekatan yang dilakukan adalah pemberian informasi oleh petugas kesehatan (bidan) langsung kepada ibu hamil tentang upaya pencegahan kejadian anemia dan KEK melalui kontak kunjungan pertama pada masa kehamilan atau ANC K1 (Antenatal Care Kunjungan Pertama). ${ }^{6}$ Kunjungan pertama (K1) ibu hamil dengan melihat besarannya sudah melebihi dari target namun K1 ini bukan K1 kohort (kunjungan dilakukan tepat waktu). Untuk mendorong agar $\mathrm{K} 1$ dilakukan tepat waktu (K1 kohort) maka pemberian informasi mengenai pentingnya kunjungan ANC harus dilakukan lebih awal. Dibutuhkan pemberian informasi jauh sebelum kehamilan ibu terjadi. Dalam hal ini terdapat faktor budaya yang dapat digunakan sebagai entry point untuk memberikan informasi sebelum kehamilan terjadi yaitu upacara adat Mappacci yang merupakan rangkaian pernikahan adat Bugis-Makassar. ${ }^{7}$

Berdasarkan hasil penelitian Citrakesumasari, Susilowati, Suriah dan Bohari tahun 2012 di Kabupaten Barru, menemukan bahwa kader posyandu dan tokoh masyarakat dapat dilatih menjadi komunikator lokal untuk menyampaikan informasi tentang pencegahan kejadian anemia gizi dan KEK pada ibu hamil. Komunikator lokal tersebut memberikan edukasi di sela-sela acara adat pengantin Bugis-Makassar (Mappacci) dilengkapi dengan media KIE (Komunikasi, Informasi dan Edukasi) berupa lembar balik dan modul yang berisi pesan terkait pencegahan anemia gizi dan KEK pada ibu hamil dikaitkan dengan simbol-simbol perlengkapan adat Mappacci. ${ }^{7}$

Di Kota Pare Pare terdapat 671 ibu hamil yang mengalami anemia dan $281 \mathrm{ibu}$ hamil yang KEK pada tahun 2016. Padahal risiko yang dapat ditimbulkan jika ibu hamil mengalami KEK yaitu bisa terjadi anemia gizi (kurang darah), melahirkan bayi dengan berat lahir rendah (BBLR), mengakibatkan anemia pada bayi baru lahir dan mudah terinfeksi. Berdasarkan data dari Laporan Program Gizi Dinkes Kota Parepare tahun 2016, bahwa jumlah ibu hamil yang mengalami KEK dan anemia terbanyak di kecamatan Bacukiki Barat wilayah puskesmas Lumpue, yakni sejumlah 203 anemia dan 72 yang mengalami KEK. Jumlah kader yang potensial untuk dilibatkan dalam mengedukasi ibu hamil terkait pencegahan KEK dan anemia juga paling banyak di kecamatan Bacukiki Barat, yakni 135 orang. ${ }^{8}$

\section{METODE PELAKSANAAN}

Uraian mengenai metode pelaksanaan kegiatan akan dikemukakan berdasarkan target luaran yang akan dicapai dalam kegiatan pengabdian ini sebagai berikut:

1. Target luaran pertama:

a. Bentuk kegiatan:

Sosialisasi dan bina suasana

b. Sasaran Kegiatan:

Petugas KUA dari 4 kecamatan se-kota

Parepare (4 orang)

Kader posyandu dan atau TOMA perwakilan

dari masing-masing kecamatan (4 orang)

Perwakilan dari bidang Upaya Kesehatan

Masyarakat Dinkes Kota Parepare (2 orang)

c. Metode:

Ceramah, presentasi, komunikasi kelompok (diskusi, tanya jawab, dan role-play) 
d. Media:

Booklet saku (untuk MC Mappacci dan TOMA pemberi Pacci yang berisi pesan gizi yang dikaitkan dengan makna simbol-simbol perlengkapan Mappacci)

e. Frekuensi: 1 Kali

f. Indikator hasil kegiatan:

Adanya komitmen peserta kegiatan sosialisasi untuk berperan sesuai tahapan pelaksanaan pengabdian yaitu petugas KUA, tokoh masyarakat, kader posyandu mengutus SDM yang akan mengikuti pelatihan komunikator lokal yang akan menyampaikan pesan anemia gizi dan KEK pada acara Mappacci.

2. Target luaran kedua:

a. Bentuk kegiatan:

Pelatihan aplikasi penggunaan media KIE tentang anemia gizi dan KEK

b. Sasaran Kegiatan:

Kader posyandu dan atau tokoh masyarakat di kecamatan Bacukiki Barat sejumlah 10 orang

c. Metode:

Ceramah, presentasi, komunikasi kelompok (diskusi, tanya jawab, dan role-play)

d. Media:

Booklet saku (untuk MC Mappacci dan TOMA pemberi Pacci yang berisi pesan gizi yang dikaitkan dengan makna simbol-simbol perlengkapan

e. Frekuensi: 1 Kali

f. Indikator hasil kegiatan:

Terlatihnya 10 orang Kader posyandu dan atau tokoh masyarakat perempuan di kecamatan Bacukiki Barat, yang terampil sebagai komunikator lokal yang akan menyampaikan tentang pesan gizi yang dikaitkan makna simbol-simbol perlengkapan Mappacci.

3. Target luaran ketiga:

a. Bentuk kegiatan:

Edukasi tentang pencegahan anemia gizi dan KEK pada ibu hamil yang dilakukan oleh kader posyandu dan atau tokoh masyarakat pada acara Mappacci di Kecamatan Bacukiki Barat.

b. Sasaran Kegiatan:

Calon pengantin yang mengadakan acara adat Mappacci di wilayah Kecamatan Bacukiki Barat

c. Metode:

Komunikasi kelompok dan komunikasi interpersonal

d. Media:

Booklet saku (untuk MC Mappacci dan TOMA pemberi Pacci yang berisi pesan gizi yang dikaitkan dengan makna simbol-simbol perlengkapan

e. Frekuensi: 1 Kali

f. Indikator hasil kegiatan:

Hasil pengamatan proses edukasi tentang pencegahan anemia gizi dan KEK pada ibu hamil yang dilakukan oleh kader posyandu dan atau tokoh masyarakat kepada calon pengantin dalam acara Mappacci di Kecamatan Bacukiki Barat.

\section{HASIL DAN PEMBAHASAN Sosialisasi dan Bina Suasana}

Sosialisasi dan bina suasana berlangsung pada tanggal 22 Agustus 2017, dihadiri oleh Tim Pengabdian Masyarakat (Dr. Suriah, S.KM, M.Kes dan Dr. dr. Citrakesumasari, M.Kes, SpGK), dan 10 orang peserta kegiatan yang terdiri dari; Petugas KUA dari 4 kecamatan se-kota Parepare (4 orang), kader posyandu perwakilan dari masing-masing kecamatan (4 orang), staf bidang gizi (1 orang) dan staf bidang promkes (1 orang) Dinkes kota Parepare. Kegiatan ini menghasilkan kesepakatan sebagai berikut:

1. Komitmen dari petugas KUA, kader posyandu dan pihak dinkes kota Parepare untuk mendukung kegiatan pengabdian dan menindaklanjuti kegiatan yang terkait dengan program mereka di instansi masing-masing.

2. Petugas KUA dan kader posyandu di wilayah kecamatan Bacukiki Barat, bersedia mengutus SDM yang akan mengikuti pelatihan komunikator lokal yang bertugas menyampaikan pesan anemia gizi dan KEK pada acara Mappacci.

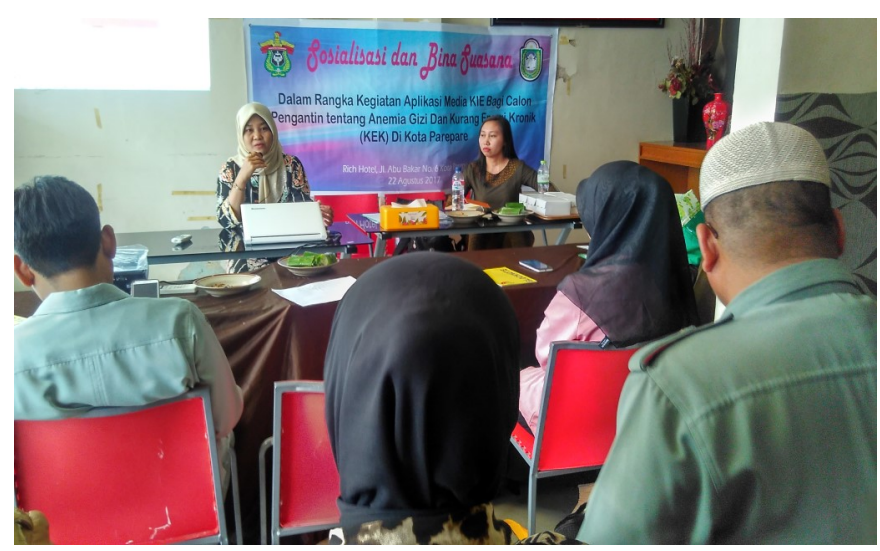

Gambar 1. Penyampaian materi dan sosialisasi

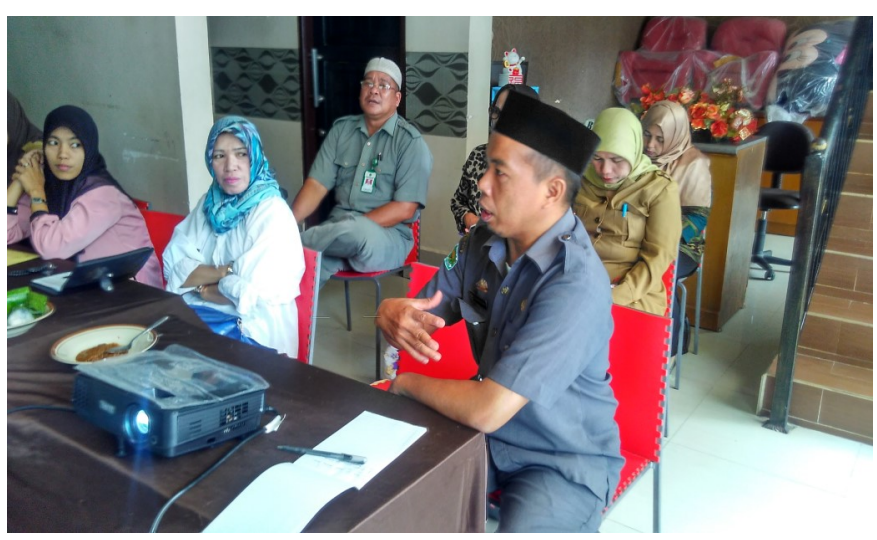

Gambar 2. Sesi tanya jawab \& diskusi

Berikut ini dokumentasi pelaksanaan kegiatan sosialisasi dan bina suasana:

Pelatihan Komunikator Lokal

Kegiatan pelatihan berlangsung selama dua hari yakni pada tanggal 26-27 Agustus 2017, dihadiri oleh Tim Pengabdian Masyarakat (Dr. Suriah, S.KM, M.Kes 
dan Awaluddin, S.KM, M.Kes), dan diikuti oleh 10 orang peserta yang terdiri dari; 9 orang kader posyandu perwakilan dari masing-masing kelurahan yang ada di kecamatan Bacukiki Barat dan salah seorang tokoh masyarakat yang merupakan Ketua RW di salah satu kelurahan di Kecamatan Bacukiki Barat. Sebelum kegiatan pelatihan dimulai, dilakukan pre-test pemahaman awal peserta pelatihan terkait anemia gizi dan KEK. Pada bagian akhir kegiatan dilakukan lagi pemahaman post-test pemahaman peserta mengenai materi pelatihan, yang meliputi pertanyaan sebagai berikut:

1. Apa yang dipahami tentang anemia gizi?

2. Apa saja tanda dan gejala anemia gizi pada ibu hamil?

3. Apa yang dipahami tentang Kekurangan Energi Kronik (KEK)?

4. Apa saja tanda KEK pada ibu hamil?

5. Apa yang dimaksud dengan tablet $\mathrm{Fe}$ ?

Tabel. 1 Hasil Pre-Post Test Pemahaman Peserta Pelatihan tentang Anemia Gizi dan KEK

\begin{tabular}{ccccc}
\hline No & $\begin{array}{c}\text { Inisial } \\
\text { Kader/ } \\
\text { TOMA }\end{array}$ & $\begin{array}{c}\text { Nilai } \\
\text { Pre-Test }\end{array}$ & $\begin{array}{c}\text { Nilai } \\
\text { Post-Test }\end{array}$ & $\begin{array}{c}\text { Bobot } \\
\text { Peningkatan }\end{array}$ \\
\hline 1 & RHN & 80 & 100 & 20 \\
2 & NRL & 80 & 100 & 20 \\
3 & AA & 60 & 80 & 20 \\
4 & WA & 40 & 60 & 20 \\
5 & IDR & 60 & 80 & 20 \\
6 & SRF & 60 & 60 & 0 \\
7 & SRY & 80 & 100 & 20 \\
8 & RSM & 60 & 80 & 20 \\
9 & SA & 80 & 100 & 20 \\
10 & ARM & 40 & 80 & 40 \\
\hline
\end{tabular}

Hasil pre-post test peserta pelatihan dapat dilihat pada tabel berikut:

Berdasarkan data hasil pre-post-test peserta pelatihan komunikator lokal tentang anemia gizi dan KEK pada tabel 1, maka tampak bahwa hampir semua peserta mengalami peningkatan pengetahuan setelah mendapatkan pelatihan. Meskipun demikian terdapat satu orang peserta pelatihan yang tidak mengalami peningkatan pengetahuan. Materi pelatihan diberikan oleh tim pengabdian sesuai dengan bidang kepakarannya. Peserta pelatihan mendapatkan materi antara lain; Anemia Gizi dan KEK pada Ibu Hamil, Sosialisasi Kegiatan Pengabdian tentang Anemia Gizi dan KEK di kecamatan Bacukiki Barat, Dinamika Kelompok dan Pengembangan Kapasitas serta Praktik Simulasi Proses Edukasi. Berikut dokumentasi proses pemberian materi pelatihan (Gambar 3).

Proses kegiatan pelatihan tidak hanya menggunakan metode ceramah dan diskusi, selain itu peserta pelatihan pelatihan dibekali dengan kemampuan berkomunikasi dan mengedukasi melalui praktik simulasi edukasi. Kemudian untuk melengkapi kemampuan komunikasi peserta diberikan media KIE berupa buklet saku untuk peran sebagai MC Mappacci dan buklet saku untuk peran sebagai TOMA Pemberi Pacci.

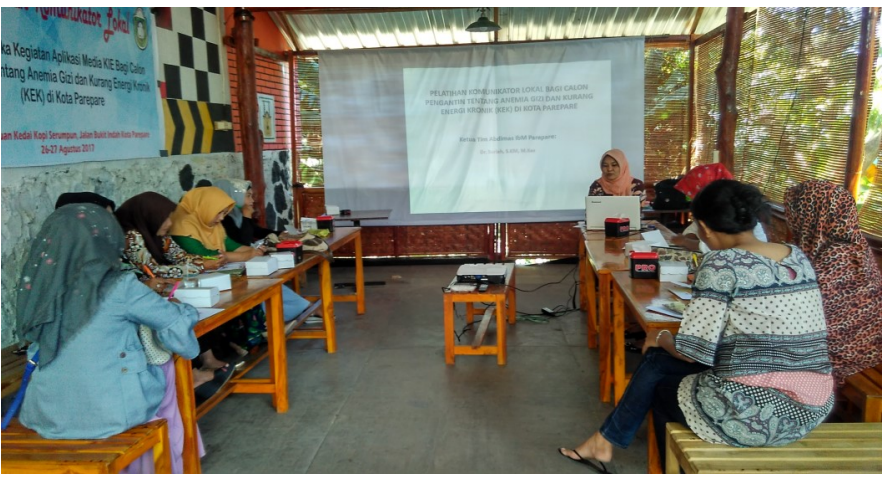

Gambar 3. Penyajian materi oleh narasumber kepada peserta pelatihan

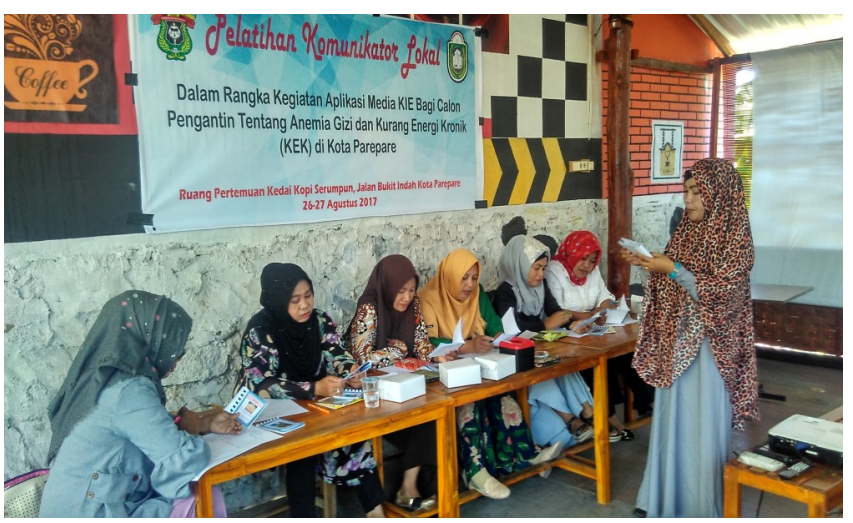

Gambar 4. Praktik simulasi edukasi peserta pelatihan yang berperan sebagai MC Mappacci

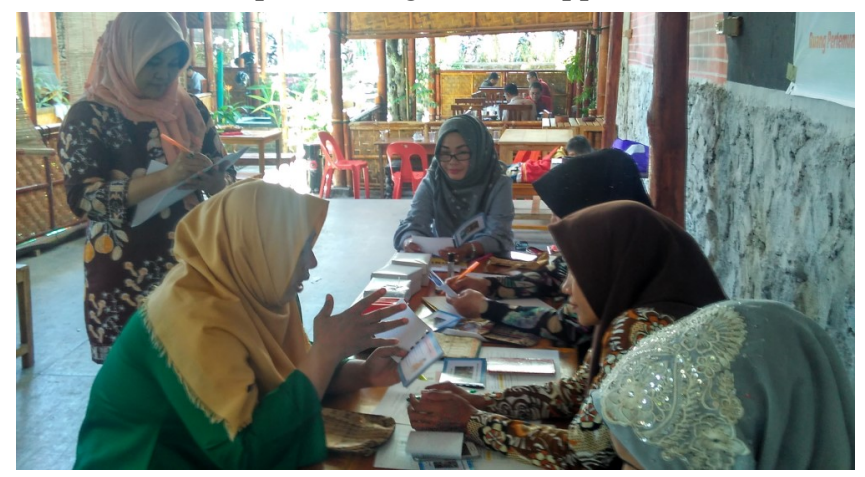

Gambar 5

Praktik simulasi edukasi sebagai TOMA Pemberi Pacci diamati oleh Tim Pengabdi dan peserta pelatihan kemudian dinilai menggunakan instrumen observasi

Proses edukasi oleh komunikator lokal diamati baik oleh sesama peserta pelatihan, maupun oleh Tim Pengabdian. Observasi proses edukasi terhadap komunikator lokal ini dimaksudkan untuk memastikan materi tentang anemi gizi dan KEK yang dikaitkan dengan simbol-simbol perlengkapan Mappacci yang telah diperoleh selama pelatihan, dapat tersampaikan kepada sasaran nantinya yaitu calon pengantin dalam acara Mappacci. Hasil observasi praktik simulasi edukasi dapat dilihat pada matriks berikut: 
Matriks 1. Hasil Observasi Praktik Simulasi Edukasi Peserta Pelatihan Berperan Sebagai TOMA Pemberi Pacci

\begin{tabular}{|c|c|c|c|c|c|c|c|c|c|c|c|c|c|c|c|}
\hline \multirow{3}{*}{$\begin{array}{c}\text { Informasi yang disam- } \\
\text { paikan }\end{array}$} & \multicolumn{15}{|c|}{ Inisial Kader/TOMA } \\
\hline & \multirow{2}{*}{$\begin{array}{l}\text { RHN } \\
\mathbf{Y}\end{array}$} & NRL & \multicolumn{2}{|c|}{$\overline{\mathbf{A A}}$} & \multicolumn{2}{|c|}{$\overline{\mathbf{W A}}$} & IDR & \multicolumn{2}{|c|}{ SRF } & SRY & RSM & \multicolumn{2}{|c|}{$\overline{\mathbf{S A}}$} & \multicolumn{2}{|c|}{ ARM } \\
\hline & & $\begin{array}{ll}\mathbf{Y} & \mathbf{T}\end{array}$ & $\bar{Y}$ & $\mathbf{T}$ & $\bar{Y}$ & $T$ & $\begin{array}{l}\mathbf{Y} \\
\end{array}$ & $\bar{Y}$ & $\bar{T}$ & $\mathbf{Y}$ & $\begin{array}{ll}\mathbf{Y} & \mathbf{T}\end{array}$ & $\bar{Y}$ & $\mathbf{T}$ & $\bar{Y}$ & $\bar{T}$ \\
\hline Tanda anemi gizi & $\sqrt{ }$ & $\sqrt{ }$ & $\sqrt{ }$ & & $\sqrt{ }$ & & $\sqrt{ }$ & $\sqrt{ }$ & & $\sqrt{ }$ & $\sqrt{ }$ & $\sqrt{ }$ & & $\sqrt{ }$ & \\
\hline Tanda KEK & $\sqrt{ }$ & $\sqrt{ }$ & $\sqrt{ }$ & & & $\sqrt{ }$ & $\sqrt{ }$ & & $\sqrt{ }$ & $\sqrt{ }$ & $\sqrt{ }$ & $\sqrt{ }$ & & & $\sqrt{ }$ \\
\hline Hindari masalah gizi & $\sqrt{ }$ & $\sqrt{ }$ & & $\sqrt{ }$ & & $\sqrt{ }$ & $\sqrt{ }$ & & $\sqrt{ }$ & $\sqrt{ }$ & $\sqrt{ }$ & $\sqrt{ }$ & & $\sqrt{ }$ & \\
\hline Kontak dengan yankes & $\sqrt{ }$ & $\sqrt{ }$ & $\sqrt{ }$ & & $\sqrt{ }$ & & $\sqrt{ }$ & & $\sqrt{ }$ & $\sqrt{ }$ & $\sqrt{ }$ & $\sqrt{ }$ & & $\sqrt{ }$ & \\
\hline Mempersiapkan data diri & $\sqrt{ }$ & $\sqrt{ }$ & $\sqrt{ }$ & & $\sqrt{ }$ & & $\sqrt{ }$ & $\sqrt{ }$ & & $\sqrt{ }$ & $\sqrt{ }$ & $\sqrt{ }$ & & & $\sqrt{ }$ \\
\hline $\begin{array}{l}\text { Memperhatikan makanan } \\
\text { bergizi }\end{array}$ & $\sqrt{ }$ & $\sqrt{ }$ & $\sqrt{ }$ & & $\sqrt{ }$ & & $\sqrt{ }$ & $\sqrt{ }$ & & $\sqrt{ }$ & $\sqrt{ }$ & & $\sqrt{ }$ & $\sqrt{ }$ & \\
\hline Mengonsumsi tablet Fe & $\sqrt{ }$ & $\sqrt{ }$ & & $\sqrt{ }$ & & $\sqrt{ }$ & $\sqrt{ }$ & & $\sqrt{ }$ & $\sqrt{ }$ & $\sqrt{ }$ & $\sqrt{ }$ & & $\sqrt{ }$ & \\
\hline
\end{tabular}

Berdasarkan hasil pengamatan oleh tim pengabdian maupun oleh sesama peserta, sebagaimana terlihat pada matriks 1, maka terlihat bahwa terdapat enam orang peserta pelatihan yang menyampaikan semua informasi terkait anemi gizi dan KEK yang diberikan pada saat pelatihan dan juga yang tertera pada buklet saku untuk peran sebagai TOMA Pemberi Pacci. Meskipun masih ada juga beberapa peserta yang tidak mampu mengingat semua pesan dan menyampaikan pada saat praktik simulasi edukasi. Beberapa pesan diantaranya yang paling sering dilupakan oleh peserta adalah tentang; tanda KEK, hindari masalah gizi dan konsumsi tablet Fe. Sedangkan hasil pengamatan terhadap praktik simulasi peserta pelatihan yang berperan sebagai MC Mappacci dapat dilihat pada matriks berikut: lokal pada acara Mappacci di wilayah Kecamatan Bacukiki Barat.

\section{Proses Edukasi}

Kegiatan edukasi oleh komunikator lokal kepada calon pengantin dalam acara Mappacci berlangsung pada tanggal 1 Oktober 2017. Kegiatan ini dilakukan oleh salah seorang kader posyandu yang telah dilatih sebagai komunikator lokal kepada salah seorang sasaran yakni calon pengantin yang mengadakan upacara adat Mappacci di wilayah Lumpue kecamatan Bacukiki Barat kota Parepare. Kegiatan ini diamati oleh Tim Pengabdian Masyarakat menggunakan lembar observasi. Hasil pengamatan menunjukkan bahwa komunikator lokal mampu menyampaikan semua informasi dalam buklet saku untuk TOMA pemberi Pacci yang berisi pesan ten-

Matriks 2 Hasil Observasi Praktik Simulasi Edukasi Peserta Pelatihan Berperan Sebagai MC Mappacci

\begin{tabular}{|c|c|c|c|c|c|c|c|c|c|c|}
\hline \multirow[b]{2}{*}{ Informasi yang disampaikan } & \multicolumn{10}{|c|}{ Inisial Kader/TOMA } \\
\hline & \multicolumn{2}{|c|}{ RHN } & \multicolumn{2}{|c|}{ NRL } & \multicolumn{2}{|c|}{ SRY } & \multicolumn{2}{|c|}{ RSM } & \multicolumn{2}{|c|}{ IDR } \\
\hline Simbol "Benno" & $\sqrt{ }$ & & $\sqrt{ }$ & & $\sqrt{ }$ & & $\sqrt{ }$ & & $\sqrt{ }$ & \\
\hline Simbol "Pesse'Pelleng" & $\sqrt{ }$ & & $\sqrt{ }$ & & $\sqrt{ }$ & & $\sqrt{ }$ & & $\sqrt{ }$ & \\
\hline Simbol "Lipa" & $\sqrt{ }$ & & $\sqrt{ }$ & & $\sqrt{ }$ & & $\sqrt{ }$ & & $\sqrt{ }$ & \\
\hline Simbol "Daun Loka" & $\sqrt{ }$ & & $\sqrt{ }$ & & $\sqrt{ }$ & & $\sqrt{ }$ & & $\sqrt{ }$ & \\
\hline Simbol "Daun Panasa" & $\sqrt{ }$ & & $\sqrt{ }$ & & $\sqrt{ }$ & & $\sqrt{ }$ & & $\sqrt{ }$ & \\
\hline Simbol “Appaccingeng” & $\sqrt{ }$ & & $\sqrt{ }$ & & $\sqrt{ }$ & & $\sqrt{ }$ & & $\sqrt{ }$ & \\
\hline
\end{tabular}

Berdasarkan informasi pada matriks 2, tampak bahwa semua peserta pelatihan yang tampil mempraktikkan peran sebagai MC Mappacci yang melakukan edukasi tentang anemi gizi dan KEK dikaitkan dengan simbol perlengkapan Mappacci dapat menyampaikan ke -tujuh pesan yang tertera pada buklet saku untuk MC Mappacci. Meskipun tidak semua peserta tampil, namun pelatihan ini dapat dikatakan mampu memberikan skill sebagai MC Mappacci yang akan menjadi komunikator tang anemia gizi dan KEK dikaitkan dengan simbolsimbol perlengkapan adat Mappacci seperti: Benno (Gabah yang digoreng kering hingga mekar), Pesse' Pelleng (Lilin dari kemiri dan kapas), Angkangulung (Bantal), Lipa' (Sarung), Daun Loka (Daun pisang), Daun Panasa (Daun Nangka) dan Appaccingeng (Wadah untuk daun pacar/pacci) berikut dokumentasi proses edukasi: 


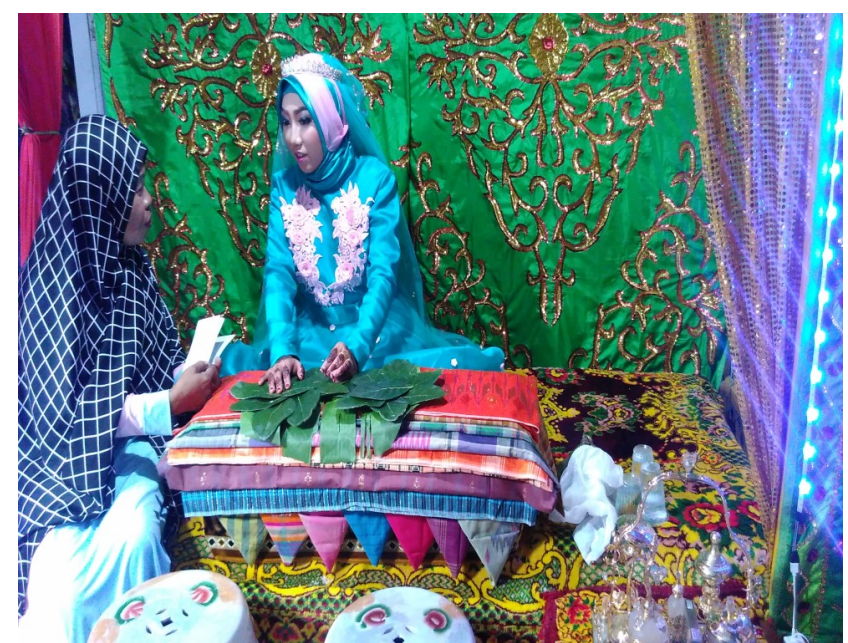

Gambar 6. Edukasi tentang anemia gizi dan KEK oleh komunikator lokal dalam acara adat Mappacci

\section{Rencana Tindak Lanjut}

Berdasarkan hasil kegiatan pengabdian ini, maka diharapkan komunikator lokal akan terus memberikan informasi yang berkelanjutan kepada calon pengantin dalam acara adat Mappacci di kota Parepare yang dilengkapi dengan booklet saku tentang anemia gizi dan KEK dikaitkan dengan simbol-simbol perlengkapan Mappacci. Di kota Parepare terdapat 4 kecamatan, sehingga diharapkan 3 kecamatan lainnya akan mengadopsi hasil kegiatan yang telah di mulai di Kecamatan Bacukiki Barat.

Beberapa hal berikut dapat menjadi upaya tindak lanjut dalam upaya mencegah kejadian anemia gizi dan KEK pada ibu hamil di seluruh wilayah kota Parepare:

a. Melakukan diseminasi informasi tentang pentingnya mendukung upaya pencegahan anemia gizi dan KEK pada ibu hamil di kota Parepare. Kegiatan ini dapat diprakarsai oleh seksi Kesehatan Ibu dan Anak (KIA), Gizi Masyarakat dan promosi kesehatan dalam lingkup dinkes kota Parepare. Selain itu mendorong partisipasi seluruh puskesmas yang ada di kota Parepare untuk turut serta melakukan penyebaran informasi ini melalui unit KIA, Gizi dan Promosi Kesehatan pada masingmasing puskesmas.

b. Pelatihan komunikator lokal di 3 kecamatan lainnya yang ada di kota Parepare yang dapat diinisiasi oleh Bidang Upaya Kesehatan Masyarakat Dinas Kesehatan kota Parepare dengan merangkul sektor di luar kesehatan seperti KUA. Peserta dapat berasal dari kader posyandu aktif, kader PKK dan tokoh masyarakat di masing-masing kecamatan.

c. Pemanfaatan dan penggandaan media edukasi berupa booklet saku tentang pencegahan anemia gizi dan KEK dikaitkan dengan simbol-simbol perlengkapan adat Mappacci bagi TOMA pemberi Pacci dan MC Mappacci. Upaya ini dapat dilakukan oleh seksi promosi kesehatan dinkes kota Parepare, dan didistribusi melalui unit promosi kesehatan di semua puskesmas yang ada di kota Parepare.

\section{KESIMPULAN DAN SARAN}

Melalui kegiatan edukasi bagi calon pengantin tentang anemia gizi dan KEK di kota Parepare, maka luaran yang telah dihasilkan adalah: 1) Komitmen dari petugas KUA, kader posyandu dan pihak dinkes kota Parepare untuk mendukung kegiatan pengabdian dan menindaklanjuti kegiatan yang terkait dengan program mereka di instansi masing-masing, 2). Sepuluh orang komunikator lokal terlatih tentang pencegahan anemia gizi dan KEK dikaitkan dengan simbol-simbol perlengkapan adat Mappacci se-kecamatan Bacukiki Barat, 3) Booklet saku tentang anemia gizi dan KEK untuk TOMA Pemberi Pacci dan MC Mappacci. Saran yang dapat diberikan berdasarkan hasil kegiatan ini adalah pihak puskesmas Lumpue dan Dinas Kesehatan kota Parepare agar dapat menyebarluaskan hasil kegiatan ini sehingga seluruh kecamatan yang ada di kota Parepare mendukung upaya pencegahan anemia gizi dan KEK pada ibu hamil yang telah dimulai di kecamatan Bacukiki Barat.

\section{DAFTAR PUSTAKA}

1. Supariasa I.N. Penilaian status gizi. Jakarta: Buku Kedokteran EGC; 2012.

2. Kemenkes RI. Laporan riskesdas 2013. Jakarta: Kementerian Kesehatan; 2013.

3. Rahmaniar A. Faktor-faktor yang berhubungan dengan KEK (Tampa Padang, Sulawesi Barat). Media Gizi Masyarakat Indonesia. 2013;1(2):98-103.

4. Aminin F, Wulandari, A., \& Lestari, R.P,. Pengaruh kekurangan energi kronis (KEK) dengan kejadian anemia pada ibu hamil. Jurnal Kesehatan. 2014;5 (2):167-72.

5. Dinkes Kota Parepare. Laporan program gizi tiga tahun terakhir di Kota Parepare. Pare-Pare: Dinas Kesehatan; 2016.

6. Citrakesumasari. Anemia gizi masalah dan pencegahannya. Yogyakarta: Kalika; 2012.

7. Citrakesumasari, Susilowati D, Suriah, Bohari. Mappacci sebagai pendekatan pemberian pemahaman calon pengantin tentang anemia gizi dan kurang energi kronik (KEK) di Kabupaten Barru (Laporan Hasil Riset Operasional Intervensi Kesehatan Ibu Dan Anak). Makassar: Pusat Humaniora, Kebijakan Kesehatan dan Pemberdayaan Masyarakat Badan Penelitian dan Pengembangan Kesehatan Kementerian Kesehatan Republik Indonesia bekerja sama dengan Program Studi Ilmu Gizi, Fakultas Kesehatan Masyarakat Universitas Hasanuddin; 2012.

8. Dinkes Kota Parepare. Laporan program gizi per wilayah puskesmas tahun 2016. Pare-Pare: Dinas Kesehatan; 2016. 
Submit your next manuscript to MPPKI

- We accept pre-submission inquiries

- Our selector tool helps you to find the most relevant journal

- We provide round the clock customer support

- Convenient online submission

- Maximum visibility for your research

Submit your manuscript at http://jurnal.unismuhpalu.ac.id/index.php/ MPPKI/index

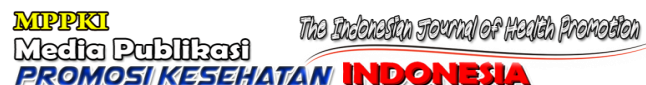

